\title{
ON THE FEASIBILITY OF ISOTOPIC ABUNDANCE MEASUREMENTS USING RAMAN SCATTERING
}

\author{
R. C. Harney \\ S. D. Bloom
}

April 18, 1974

Prepared for U.S. Atomic Energy Commission under contract No. W-7405-Eng-48
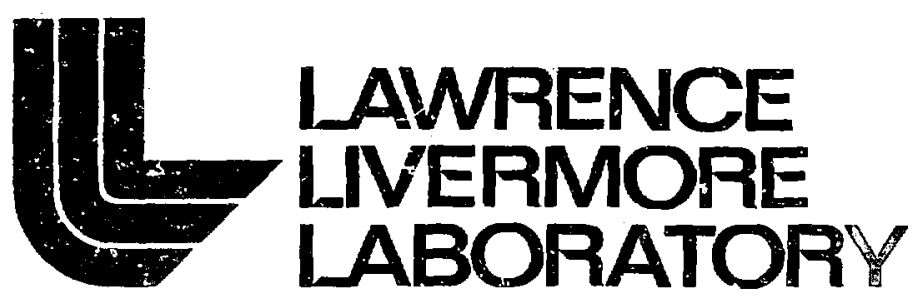

University of California/Livermore

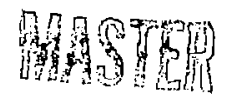

DISTRIEUTION OS JEIS DOCUMENT IS UNLIMITEO 


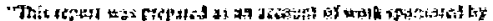

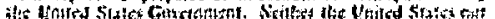

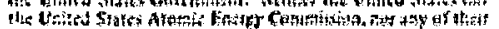

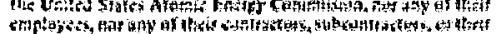

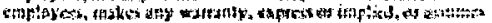

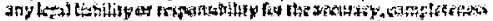

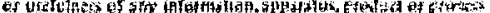
(2) opend bithti:-

Printed in the United States of America Avaílable: from

Naticnal Technical Iriormation Service U.S. Department of Commeree 5205 Pori Royal Road Springfield, Virginia 22251

Price: Printed Copy $\$$; Mictofiche $\$ 2.95$

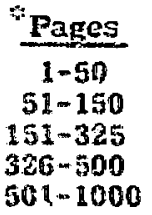

NTIS

Sollint Price

89.00

58.45

57.60

$\$ 10.60$

513.60 


\section{辺 \\ LAMFENCE INEFMOAE LABOFATOAY

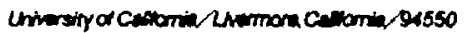

$\because C R L-51558$

\section{ON THE FEASIBILITY OF ISOTOPIC ABUNDANCE MEASUREMENTS USING RAMAN SCATTERING}
R. C. Harney
S. D. Bloom

MS. Dale: April 18, 1074

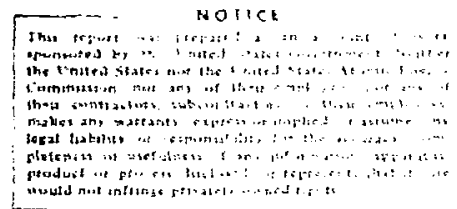

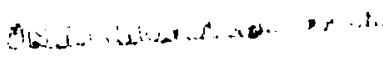




\title{
ON THE FEASIBILITY OF ISOTOPIC ABUNDANCE MEASUREMENTS USING RAMAN SCATTERING
}

\begin{abstract}
The possibility of using gas-phase Raman scattering of laser beams for measuring the isotopic abundances of light elements is studied. A design for a Raman scattering isotopic abundance spectrometer is presented, and the data collection rate for a natural isotopic abundance determination in nitrogen

gas is calculated. An analysis of noise sources indicates that isotopic variations of lese than 100 parts per billion may be measured in times of the order of a few minutes. It appears that laser Raman scattering should be a valuable new tool for precision assays of isotopic abundance ratios.
\end{abstract}

Isotopic abundance measurements are being used at an ever-increasing rate in chemical and biological research. ' For radioactive isotopes, the abundances are easily determined using nuclear counters. For nonradioactive isotopes, mass spectrometers have been essentlally the only available tools. In general, a precision measurement (error of $\pm 0.1 \%$ or less) of an isotopic abundance ratio takes on the order of tens of minutes or more using a mass spectrometer. In addition, the sample is altered (i. e.. jonized and possibly fragmented) as well as consumed during the measurement. A technique in which the measurement time is reduced significantly and the sample is neither consumed nor altered might be of considerable intcregt. Here, we describe a new approach, laser Raman scattering, which should fulfill these conditions. We limit our study (for the present) to the light elements (hydrogen, boron, carbon, nitrogen, and oxygen), though some mention of heavier elements is made later. We begin with a discussion of isotope effects in Raman scattering and then describe a design for a practical system incorporating the necessary dispersive elements as well as an argon ion laser source. Finally, estimates are made of the range of applicability of the Raman scattering techrique.

Raman scattering is the inelastic scattering of light by molecules. ${ }^{2}$ The elementary processes are indicated in Fig. 1 for the case of the excitation of molecular vibrations, which is of prime interest in the present context. In Stokes Raman scattering, a laser photon of energy $\pi \omega_{\bar{L}}$ scatters from a molecule in its ground state, losing an amount of 
Excited

electronic $\hbar \omega_{1}$

states

Virtuol

intermediate states

$$
\hbar\left(w_{v}+w_{L}\right)
$$

$\hbar \omega_{L}$

First excited

vibrational two

state

Grounci state 0

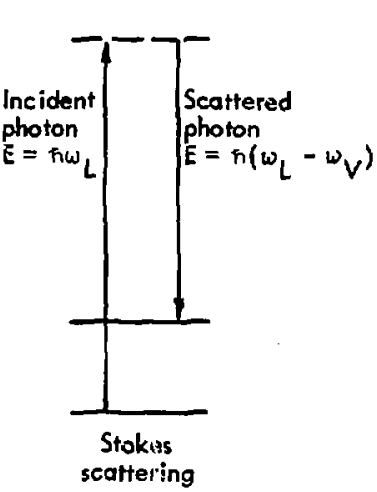

Fig. 1. The Rarnan effect: Stokes and anti-Stokes scattering.

energy equal to one quantum of vibrational energy ( $\left.k \omega_{v}\right)$. The molecule is left in an excited state, while the scattered photon has an energy $n\left(\omega_{L}-\omega_{v}\right)$. In antí-Stokes scattering, the laser photon scatters from a molecule in its first excited vibrational state, gaining an amount of energy equal to one quantuns of vibrational energy. In this case the scattered photon has an energy $\hbar\left(\omega_{I_{d}}+\omega_{v}\right)$. The relative intensities of Stokes and antiStokes scattering are temperature dependent; the ratio is given by the Boltzmann factor,

$$
\frac{I_{\text {enti-Stokes }}}{I_{\text {Stokea }}}=\mathrm{e}^{-\hbar \omega_{\mathrm{v}} / k T} \text {. }
$$

The Raman cross section will depend on $w_{L}$, as well as on $w_{v}$ and other char- acteristics of the scattering molecule. Substitution of one isotope for another in a molecule usually changes the vibrational frequency roughly inversely as the square root of the effective mass. In simple molecules this frequency shift, knuwn as the isotope effect, can be sufficiently large $\left(1 \mathrm{~cm}^{-1}\right.$ or greater) so that the Raman frequencies corresponding to different isotopes can be easily resolved by a monochromator. Table 1 lists the natural isotopic abundances of some important elements while Table 2 shows the isotope effect in the vibrational frequencies of aeveral simple molecules.

If the element to be analyzed in a a ample can be quantitatively conver ted to a single molecular species that exhibits an easily detectable Raman isotope effect, then Raman scattering may be 
Table 1. Natural isotopic abundances of selected elements.

\begin{tabular}{|c|c|c|c|c|c|}
\hline Element & Irotope & $\underset{(\%)}{\text { Abundance }}$ & E) ement & Isotope & $\begin{array}{c}\text { Abundince } \\
(\%)\end{array}$ \\
\hline \multirow[t]{3}{*}{ Hydrogen } & ${ }^{1} \mathrm{H}$ & 99.985 & \multirow[t]{2}{*}{ Chlorine } & \multirow{2}{*}{$\begin{array}{l}{ }^{35} \mathrm{Cl} \\
{ }^{37} \mathrm{Cl}\end{array}$} & 75.77 \\
\hline & ${ }^{2} \mathrm{HI}$ & 0.015 & & & 24.23 \\
\hline & ${ }^{3} \mathrm{H}$ & - & \multirow[t]{3}{*}{ Potassium } & ${ }^{39} K$ & 93.08 \\
\hline \multirow[t]{2}{*}{ Lithium } & ${ }^{6}{ }_{\mathrm{Li}}$ & 7.56 & & ${ }^{40} \mathrm{~K}$ & 0.0118 \\
\hline & ${ }^{7} \mathrm{Li}$ & 92.44 & & ${ }^{41} \mathrm{~K}$ & 6.91 \\
\hline \multirow[t]{2}{*}{ Boron } & ${ }^{10} \mathrm{~B}$ & 19.8 & \multirow[t]{4}{*}{ Iron } & ${ }^{54} \mathrm{Fe}$ & 5.8 \\
\hline & ${ }^{11} B$ & 80.2 & & ${ }^{56} \mathrm{Fe}$ & 91.7 \\
\hline \multirow[t]{3}{*}{ Carbon } & ${ }^{12} \mathrm{C}$ & 98.89 & & ${ }^{57} \mathrm{Fe}$ & 2.14 \\
\hline & ${ }^{13} \mathrm{C}$ & 1.11 & & ${ }^{58} \mathrm{Fe}$ & 0.31 \\
\hline & ${ }^{14} \mathrm{C}$ & - & \multirow[t]{2}{*}{ Rubidium } & ${ }^{85} \mathrm{Rb}$ & 72.15 \\
\hline \multirow[t]{2}{*}{ Nitrogen } & ${ }^{14} \mathrm{~N}$ & 99.6 .3 & & ${ }^{87} \mathrm{Rb}$ & 27.85 \\
\hline & $15 \mathrm{~N}$ & 0.37 & \multirow[t]{7}{*}{ Mercury } & ${ }^{196} \mathrm{Hg}$ & 0,146 \\
\hline \multirow[t]{3}{*}{ Oxygen } & ${ }^{16} \mathrm{O}$ & 99.759 & & ${ }^{198} \mathrm{Hg}$ & 10.02 \\
\hline & ${ }^{13} \mathrm{O}$ & 0.037 & & ${ }^{199} \mathrm{Hg}$ & 16.84 \\
\hline & ${ }^{18} \mathrm{O}$ & 0.204 & & ${ }^{200} \mathrm{Hg}$ & 23.13 \\
\hline \multirow[t]{3}{*}{ Silicon } & ${ }^{28} \mathrm{Si}$ & 92.21 & & ${ }^{201} \mathrm{Hg}$ & 13.22 \\
\hline & ${ }^{29} \mathrm{Si}$ & 4.70 & & $209 \times 5$ & 29.80 \\
\hline & ${ }^{30} \mathrm{Si}$ & 3.09 & & ${ }^{204} \mathrm{Hg}$ & 6.85 \\
\hline \multirow[t]{4}{*}{ Sulfur } & $32 \mathrm{~s}$ & 95.00 & \multirow[t]{4}{*}{ Uranium } & ${ }^{234} \mathrm{U}$ & 0.0057 \\
\hline & $33 \mathrm{~s}$ & 0.76 & & $235 \mathrm{U}$ & 0.72 \\
\hline & ${ }^{34} \mathrm{~S}$ & 4.22 & & ${ }^{238} \mathrm{U}$ & 99.27 \\
\hline & ${ }^{36} s$ & 0.014 & & & \\
\hline
\end{tabular}

used for performing the isotopic analysis. Examples of such elements are carbon and nitrogen. Carbon in any substance is readily converted to $\mathrm{CO}_{2}$ upon combustion, and nitrogen in almost any form is converted to $\mathrm{N}_{2}$ by the Dumas method. ${ }^{8}$ The intens ity $I_{i}$ (in photons $-\mathrm{sec}^{-1}-\mathrm{sr}^{-1}$ ) of Stokes Raman scattering from molecules of type $i$ is given by

$$
I_{i}=p_{i} \sigma_{i} \phi L,
$$

where we suppress the dependence on scattering angle and polarization, since these are not important in the rresent discussion. In Eq. (2) $\rho_{i}$ is the number density in $\mathrm{cm}^{-3}$ and $\sigma_{i}$ is the differential Raman cross section (usually at $90^{\circ}$ ) in $\mathrm{cm}^{2}-\mathrm{sr}^{-1}$, both pertaining 10 type i molecules; $\phi$ is the incident lafer intensity (photons- $\sec ^{-1}$ ); and $L$ is the length of the scattering volume. Since the isotopic molecular abundances $\mathbf{N}_{\mathbf{i}}$ are given by

$$
\left.N_{i}=\rho_{i}\right\} \sum_{a \| j} \rho_{j},
$$

it is clear that, given the quantities $\sigma_{i} \rightarrow \mathrm{L}$, the $N_{i}$ can be obtained by measuring the $I_{i}$. 
Table 2. The isotope effect in selected molscules.

\begin{tabular}{|c|c|c|c|c|c|}
\hline Molecule & $\left(\mathrm{cm}^{\omega_{v}}-1\right)$ & $\begin{array}{l}\text { Ref. } \\
\text { No. }\end{array}$ & Molecule & $\begin{array}{c}\omega_{v} \\
\left(\mathrm{~cm}^{-1}\right)\end{array}$ & $\begin{array}{l}\text { Ref. } \\
\text { ivo. }\end{array}$ \\
\hline $\mathrm{H}_{2}$ & 4161.1 & 3 & ${ }^{\mathrm{T}} \mathrm{BF}_{3}$ & 482.0 & 6 \\
\hline $\mathrm{HD}$ & 3632.1 & 3 & ${ }^{11} \mathrm{BF}_{3}$ & 480.4 & 6 \\
\hline $\mathrm{D}_{2}$ & 2994.4 & 4 & \multirow{3}{*}{$\begin{array}{l}{ }^{12} \mathrm{C}^{16} \mathrm{O}_{2} \\
{ }^{13} \mathrm{C}^{16} \mathrm{O}_{2}\end{array}$} & & \\
\hline $\mathrm{HT}$ & 3433.1 & 4 & & 1388.2 & 7 \\
\hline DT & $\sim 2686.0^{a}$ & 4 & & 1369.9 & 7 \\
\hline \multirow{2}{*}{$\mathbf{T}_{2}$} & 2466.1 & 4 & \multirow{5}{*}{$\begin{array}{l}{ }^{12} \mathrm{c}^{32} \mathrm{~S}_{2} \\
{ }^{12} \mathrm{c}^{32} \mathrm{~S}^{33} \mathrm{~S} \\
{ }^{12} \mathrm{c}^{32} \mathrm{~s}^{34} \mathrm{~S}\end{array}$} & & \\
\hline & & & & 658.0 & 7 \\
\hline${ }^{6} \mathrm{Li}_{2}$ & $-373.9^{a}$ & 4 & & 653.0 & 7 \\
\hline${ }^{6} \mathrm{Li}^{7} \mathrm{Li}$ & $-360.3^{a}$ & 4 & & 648.4 & 7 \\
\hline \multirow[t]{2}{*}{${ }^{7} \mathrm{Li}_{2}$} & 346.2 & 4 & & & \\
\hline & & & \multirow{3}{*}{$\begin{array}{l}{ }^{12} \mathrm{C}_{6} \mathrm{H}_{6} \\
12 \mathrm{C}_{5}{ }^{3}{ }^{3} \mathrm{CH}_{6}\end{array}$} & 991.6 & 6 \\
\hline & 2330.7 & 4 & & 984 & $E$ \\
\hline${ }^{14} \mathrm{~N}^{15} \mathrm{~N}$ & $\sim 2291.5^{2}$ & 4 & & & \\
\hline \multirow{2}{*}{${ }^{15} \mathrm{~N}_{2}$} & $\sim 2251.7^{a}$ & 4 & \multirow{3}{*}{$\begin{array}{l}{ }^{12} \mathrm{C}_{6} \mathrm{D}_{6} \\
{ }^{12} \mathrm{C}_{5}{ }^{13} \mathrm{CD}_{6}\end{array}$} & 924.7 & 6 \\
\hline & & & & 939.5 & 6 \\
\hline & 1556.3 & 5 & & & \\
\hline${ }^{17} \mathrm{O}_{2}$ & $-1509.8^{\mathrm{a}}$ & 5 & ${ }^{12} \mathrm{C}^{35} \mathrm{Cl}_{4}$ & 461.5 & $\theta$ \\
\hline & $-1467.3^{a}$ & 5 & ${ }^{12} \mathrm{C}^{35} \mathrm{Cl}_{3}{ }^{37} \mathrm{Cl}$ & 458.4 & $1:$ \\
\hline${ }^{16} \mathrm{C}^{17} \mathrm{O}$ & $\sim 1533.2^{\mathrm{a}}$ & 5 & ${ }^{12} \mathrm{C}^{35} \mathrm{Cl}_{9}{ }^{37} \mathrm{Cl}_{2}$ & 455.1 & 6 \\
\hline${ }^{16} \mathrm{O}^{18} \mathrm{O}$ & $\sim 1512.5^{\mathrm{a}}$ & 5 & ${ }^{12} \mathrm{C}^{55} \mathrm{Cl}^{3 / 7} \mathrm{Cl}_{3}$ & $-452.0^{a}$ & 6 \\
\hline${ }^{17} \mathrm{o}^{18} \mathrm{O}$ & $\sim 1488.7^{a}$ & 5 & ${ }^{12} \mathrm{C}^{37} \mathrm{Cl}_{4}$ & $\sim 448.9^{\mathrm{a}}$ & 6 \\
\hline
\end{tabular}

$a_{A}$ calculateo frequency.

Consider the proposed system shown in Fig. 2. A lacer beam is focused into a cell containing the sample to be analyzed. The scattered light is collected by a pair ot lenses and directed into two double monichromators. Each monochromator isolates a particular isotopic Raman frequency. A photomultiplier and scaler system at the output slit of each monochromator counts the number of Raman-scattered photons. For the ith isotopic line and the $m$ th monochromator, the count rate $R_{i m}$ is given by

$$
R_{i m}=\epsilon_{m}^{\gamma}{ }_{m i} \rho_{i}^{\sigma} \phi^{\phi L}=\epsilon_{m}^{\gamma}{ }_{m i} I_{i},
$$

where $\epsilon_{m}$ is the collection efficiency of the rnth lens system and $\gamma_{\mathrm{mi}}$ is the efficiency of the mth monochromator and photomuliiplier system at the scattered wavelength. The ratio of the count rates observed for two lines $i$ and $j$ is

$\frac{R_{i 1}}{R_{j 2}}=\left(\frac{\epsilon_{1}{ }_{1 j}{ }^{\sigma} i}{\epsilon_{2}^{\gamma} 2 j^{\sigma} j}\right) \frac{\rho_{i}}{\rho_{j}}=\alpha_{i j} \frac{p_{i}}{\rho_{j}}$.

Calibration with a sample whose $\rho_{i}$ and $\rho_{j}$ values have been determined by mass spectrometer measurements yields the constants $\alpha_{i j}$. Once the $\alpha_{i j}$ are known, the $p_{i}$ of other samples may be determined 


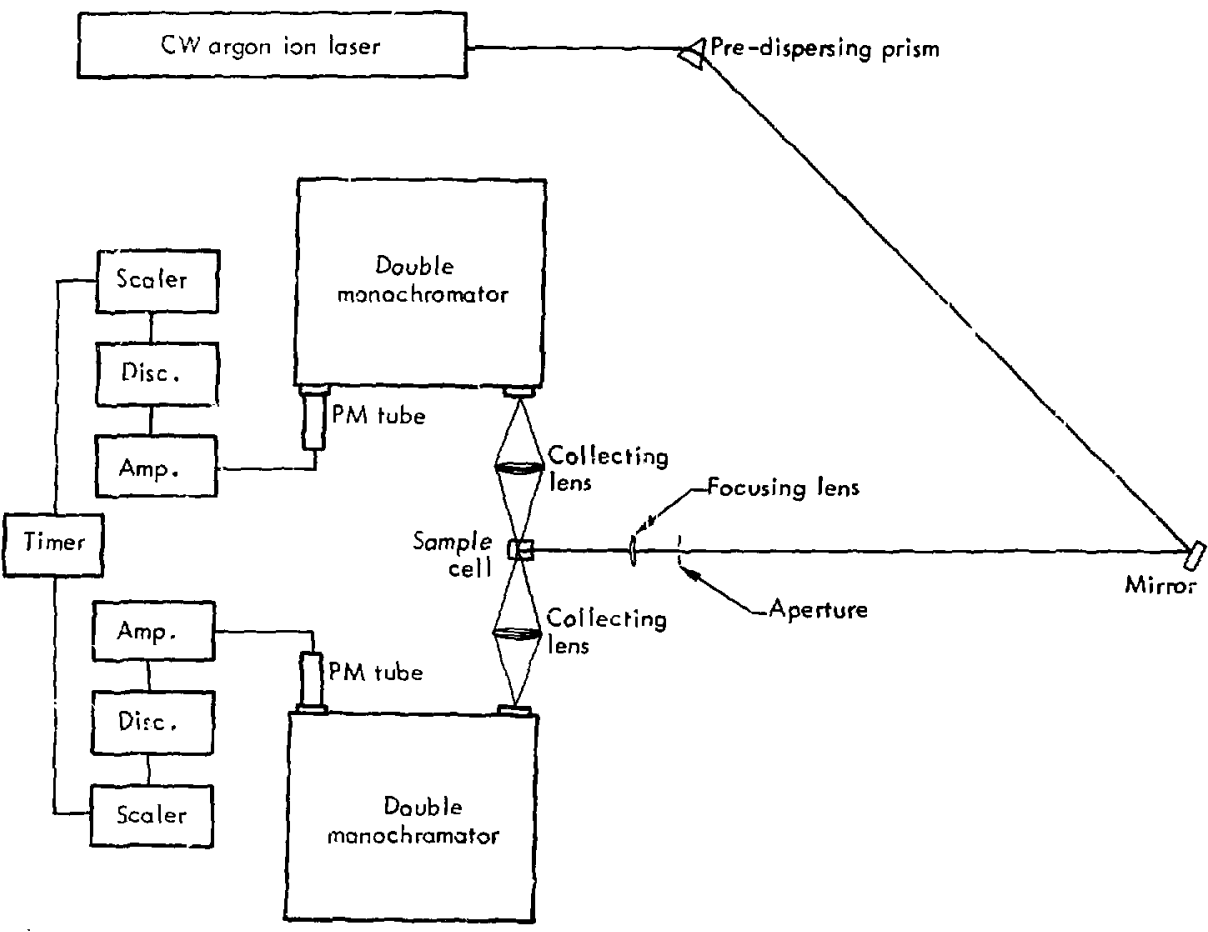

Fig. 2. Schematic diagram of a laser Raman scattering isotopic abundance spectrometer.

by measuring the $R_{i}$. It is of course possible to use a single monochromator by using a periodic scanning procedure to sample the different isotopic lines.

At th: 3 point it is instructive to calculate $\mathrm{R}$ for the case of nitrogen gas, because it is a practical example for the types of problems one would expect in real isotopic abundance measurements. Consider a sample at 1 atm $\left\{p=2.7 \times 10^{19}\right.$ $\mathrm{cm}^{-3}$, with $L=1 \mathrm{~cm}$, and a photon flux of $\phi=1.2 \times 10^{19}$ phutons $-\mathrm{sec}^{-1}$. This flux corresponas to a laser power of $5 \mathrm{~W}$ at $4880 \AA$ and is characteristic of commercialiy available argon ion lasers. From Table 3 , the $90^{\circ}$ differential cross sectioni for nitrogen is $\sigma=3.3 \times 10^{-3}$. $\mathrm{cm}^{2}-\mathrm{sr}^{-1}$. Thus, from Eq. (2) $I=1.1 \times 10^{8}$ phw.ons-sec ${ }^{-1}-s r^{-1}$.

An $f / 7$ monochromator (effective solid ang?e of $0.02 \mathrm{sr}$ ) and a photomultiplier tube with a quantum efficiency of $25 \%$ (e. g., a selected RCA C. 1034 ) yields $\epsilon \gamma \approx 0.005 \mathrm{sr}$, which is a reasonable figure. Thus from Eq. (4),

$$
R=5.5 \times 10^{5} \text { counts }-\sec ^{-1} \text {. }
$$

\footnotetext{
"Reference to a company or product name does not imply approval or recommendation of the product by the University of California or the U.S. Atomic Energy Commission to the exclusion of others that may be suitable.
} 
Table 3. Raman cross sections for selected molecules (4BRO $\AA$ excitation).

\begin{tabular}{lclc}
\hline Molecuin & $\begin{array}{c}\text { Raman shift, } w_{\mathrm{v}} \\
\left(\mathrm{cm}^{-1}\right)\end{array}$ & $\begin{array}{c}\text { Differential cross section, do } / \mathrm{d} \Omega \\
\left(\mathrm{cm}^{2}-\mathrm{moI}^{-1}-\mathrm{sr}\right)\end{array}$ & $\begin{array}{c}\text { Ref. } \\
\text { No. }\end{array}$ \\
\hline $\mathrm{C}_{6} \mathrm{H}_{6}$ & 992 & $3.25( \pm 0.10) \times 10^{-29}$ & 9 \\
$\mathrm{C}_{6} \mathrm{H}_{5} \mathrm{CH}_{3}$ & 1002 & $1.83( \pm 0.06) \times 10^{-29}$ & 9 \\
$\mathrm{C}_{6} \mathrm{H}_{5} \mathrm{NO}_{2}$ & 1345 & $1.03( \pm 0.04) \times 10^{-28}$ & 9 \\
$\mathrm{CS}_{2}$ & 656 & $4.35( \pm 0.13) \times 10^{-29}$ & 9 \\
$\mathrm{CCl}_{4}$ & 459 & $2.25( \pm 0.07) \times 10^{-29}$ & 9 \\
$\mathrm{~N}_{2}$ & 2331 & $3.3( \pm 1.1) \times 10^{-31}$ & 10 \\
$\mathrm{O}_{2}$ & 1556 & $4.3( \pm 1.4) \times 10^{-31}$ & 10 \\
$\mathrm{H}_{2}$ & $416)$ & $7.9( \pm 2.6) \times 10^{-31}$ & 10 \\
$\mathrm{CO}_{2}$ & 1388 & $4.6( \pm 1.5) \times 10^{-31}$ & 10 \\
$\mathrm{H}_{2} \mathrm{O}$ & 3652 & $8( \pm 3) \times 10^{-31}$ & 11 \\
$\mathrm{NH}_{3}$ & 3334 & $1.65( \pm 0.55) \times 10^{-30}$ & 10 \\
$\mathrm{ND}_{3}$ & 2420 & $9.9( \pm 3.3) \times 10^{-31}$ & 10 \\
\hline
\end{tabular}

This is of course the rate characteristic of the high-abundance peak $\left({ }^{14} \mathrm{~N}_{2}\right)$. The low-abundance peak $\left({ }^{14} \mathrm{~N}^{15} \mathrm{~N}\right)$ would have a rate of approximately 4000 counts $-\mathrm{sec}^{-1}$. Thus an isotopa ratio measurement to a precision of appzoximately $\pm 0.1 \%$ would require 5 to $10 \mathrm{~min}$, exclusive of possible noise limitations, which we now consider.

The precisional limit of the Raman scatiering technique as well as the minimum detectable quantity is prescribed by the counting statistics. For example, in a totally noise-free situation, 100 counts on the weak line must be obtained to determine the isotope ratio to an accuracy of $10 \%$. At the 1 part per million level of the low-abundance element, $10^{8}$ counts will be obtained on the strong line. This takes about $5 \mathrm{~min}$ at the typical count rate calculated earier. However, two factors contribute to noise in the Raman scattering technique: stray light and ghosts from the gratirgs, and thermal noise in the photomultiplier. Cooling the photo- multiplier tube to liquid nitrogen temperature reduces the thermal noise to less than 0.1 counts- $\sec ^{-1}$. I a double monochromator using hologri. inic gratings, ghosts are absent, and the stray light intensity is less than $10^{-12}$ of the input intensity. ${ }^{12}$ The ajority of this input intensity is Rayleigh-scattered light from the sample." Since the Rayleigh attenuation factor of nitrogen at 1 atm is $0.02 \mathrm{~km}^{-1}$ (Ref. 13), which corresponds to $\rho \sigma=$ $1.6 \times 10^{-8} \mathrm{~cm}^{-1}-5 \mathrm{r}^{-1}$, the Rayleigh scattered intensity is $I \approx 3.2 \times 10^{11}$ photons-6ec ${ }^{-1}-\mathrm{sr}^{-1}$. Applying the spectrometer efficiency $E \gamma \approx 0.005 \mathrm{sr}$ and the $10^{-12}$ attenuation factor, the stray-light noise is approximately $10^{-3}$ counts- $\sec ^{-1}$. Thus, we see that only the noise level of the photomultiplier limits the minimum detectable quantity.

\footnotetext{
${ }^{\frac{T}{7}}$ Rayleigh (or Brillouin) scattering is several orders of magnitude stronger than Raman scattering in transparent liquids or gases.
} 
A signal-to-noise ratio of 1 yields better than $10 \%$ accuracy if $10^{3}$ counts are obtained. Thus for a count time of $10^{4} \mathrm{sec}$ and a maximum count-rate of $10^{6} \sec ^{-1}$ (2chievable with fast electronics) one could collect $10^{10}$ counts on the strong line and $10^{3}$ noise counts. This means that an abundance of 100 parts per billiors is measurable to less than about $10 \%$ accuracy. Since the noise figure used is an upper limit, abundances down to 10 garts per billion should be measurable. Another way of exhibiting the potential performance of the Raman technique is in the precision to which isotopic abundances such as ${ }^{12} \mathrm{C} /{ }^{13} \mathrm{C}$ could be measured. Using the same basic data as above it is easy to show i lat an isotope ratio measurement with a precision of $\pm 0.1 \%$ would require 2 to $5 \mathrm{~min}$, similar to the results already quoted for ${ }^{14} \mathrm{~N} /{ }^{15} \mathrm{~N}$. Measuring the ${ }^{16} \mathrm{O} /{ }^{18} \mathrm{O}$ ratio would also yield results in the same time range. A typical mass spectrograph measurement of any of these ratios to the same precision would require approximately $30 \mathrm{~min}$.

The main limitation of the Ramas technique is that the element to be analyzed must be quantitatively incorporated into a molecule, showing an easily deteciatle isotope effect. A similar probli:m is present in mass spectroscopy. However, in the Raman scattering technique samples can be prepared and encapsulated in standard forms in advance of any measurement. Furthermore, the measurement itself is easily standardized . nd can be repeated as often as desired on the same sample. Finally, many new media, otherwise totally intractable, are approachable using the Raman technique, liquids in certain cases being a good example. Examples of tractable (for our purposes) substances are: hydrogen in $\mathrm{H}_{2} \mathrm{O}$, lithium in $\mathrm{Li}_{2}$ vapor (at $1000^{\circ} \mathrm{C}$ ), boron in $\mathrm{BF}_{3}$, carbon in $\mathrm{CO}_{2}$, nitrogen in $\mathrm{N}_{2}$, oxygen in $\mathrm{CO}_{2}$ and $\mathrm{H}_{2} \mathrm{O}$, sulfur in $\mathrm{SO}_{2}$, chlorine in $\mathrm{CCl}_{4}$ (liquid), and uranium in $\mathrm{UF}_{6}$ or $\mathrm{UO}_{2}^{2+}$ (acidic aqurous solution). In molecules where tiree or more isotopes may be present, a large number of isotopic lines may have to be monitored. This is possible, but the time required to collect all the necessary data is in direct proportion to the number of lines. Of the materials in the list we have given, only $B F_{3}$ and $N_{2}$ escape this possible difficulty. In $\mathrm{BF}_{3}$ there are only two isotopic molecules; while there are three in $\mathrm{N}_{2}$. However, $\mathrm{N}_{2}$ is a special case. For an ${ }^{14} \mathrm{~N}$ concentration $x$ and an ${ }^{15} \mathrm{~N}$ concentration $\mathrm{y}$, the kinetice of $\mathrm{N}_{2}$ formation favor the statistical $\mathrm{x}^{2}$ : 2xy:y ratio for ${ }^{14} \mathrm{~N}_{2}:{ }^{14} \mathrm{~N}^{15} \mathrm{~N}:{ }^{15} \mathrm{~N}_{2}$. The equilibrium value of these ratios is not $x^{2}: 2 x y: y^{2}$, yet the equilibration time is so long that in plactice equilibrium will never be reached. As a result, the ${ }^{14} \mathrm{~N}$ and ${ }^{15} \mathrm{~N}$ concentrations can be determined by inference from a measurement of only the ${ }^{14} \mathrm{~N}_{2}$ and ${ }^{14} \mathrm{~N}^{15} \mathrm{~N}$ lines.

As already noted, sample preparation and handling in the laser Raman scattering technique are generally the same for gaseous samples as in the mass spectroscopic technique. For best results the scattering cells should be filled on a cryogenic vacuum line. For the Raman technique sample size should not pose a serious drawback. A typical reusable sample cell would have a volume of $1 \mathrm{~cm}^{3}$. while a sealed-capillary cell could have a volume as small as $10^{-2} \mathrm{~cm}^{3}$, all at 1 atm: Using the latter, micromole 
quantities of gas may be analyzed. It is also possible to analyze smaller samples by using lower pressure, although the count rates will be decreased proportionately.

In conclusion, we suggest that laser Raman scattering using photon counting techniques should be useful for measuring isotopic abundances of many elements. A typical spectrometer (Fig. 2) would consist of a high-power argon ion laser, a scattering cell and collecting optics, two double monochroinators, and two photon counting systems. The technique's applicability to nitrogen and oxygen should prove of significant utility in the use of ${ }^{15} \mathrm{~N}$ and ${ }^{18} \mathrm{O}$ as nonradioactive tracers.

\section{Acknowledgments}

We should like to express our thanks to Ur. R. A. Fisher and Dr. M. M. Johnson for their help, advice, and interest in the early phases of this work, and to Prof. J. H. Reynolds for his comments on the general aspects of mass spectroscopy bearing on our study. In adcition, one of us ( $\mathrm{RCH}$ ) should like to thank Dr. L. W. Coleman for his encouragement and support of this effort. 


\section{References}

1. For examples, see Proceedings of the First Internationa' Conference on Stable Isotopes in Chemistry, Biology, and Medicine, CONF-730525, L.S. Atomic Energy Commission (1973).

2. For an introduction to Raman scattering refer to The Raman Effect. A. Anderson, Ed, (Marcel Dekker, New York, 1973), Vol. I and II.

3. B. Stoichei:, Can. J. Phys. 32, 630 (1954).

4. G. Herzberg, Spectra of Diatomic Molecules (Van Nostrand Reinhold Co., New York, 1950).

5. A. Weber and E. McGinnis, J. Mol. Spectrosc. 4, 195 (1960).

6. G. Herzberg, Infared and Raman Spectra (Van Nostrand Reinhold Co., New York, 1945).

7. B. Stoicheff, Can. J. Phys. 36, 218 (1958).

8. D. A. Skoog and D. M. West, Fundamentals of Analytical Chemistry (Holt, Rinehart, and Winston, New York, 1969), p. 316.

9. Y. Kato and H. Takuma, J. Opt. Soc. Amer. 61, 347 (1971).

10. W. R. Fenner, H. A. Hyatt, J. M. Kellam and S. P. S. Porto, J. Opt. Soc. Amer. 63, 73 (1973).

11. C. M. Penney, L. M. Goldman, and M. Lapp, Nature Physical Science 235. 110 (1972).

12. The properties of 'nonochromators employing holographic gratings are discussed in Handbook of Diffraction Gratings: Ruled and Holographic (available from JobinYvon Optical Systems, 20 Highland Avenue, Metuchen, New Jersey 08840).

13. Handbook of Lasers, R. J. Pressley, Ed. (Chemical Rubber Co., Cleveland, 1971), p. 41. 